\title{
Delivering Post-Secondary STEM Education on the North Slope, Alaska: Resilience and Adaptation
}

\author{
Linda Nicholas-Figueroa \\ Iḷisaġvik College, Barrow Alaska, United States
}

Ray Barnhardt

University of Alaska Fairbanks, United States

Lawrence K. Duffy (Corresponding author)

University of Alaska Fairbanks, United States

Kriya Dunlap

University of Alaska Fairbanks, United States

Mary van Muelken

University of Alaska Fairbanks, United States

Catherine H. Middlecamp

University of Wisconsin-Madison, United States

Received: May 6, 2015 Accepted: June 1, 2015 Published: June 17, 2015

doi:10.5296/ire.v3i2.7555

URL: http://dx.doi.org/10.5296/ire.v3i2.7555

\begin{abstract}
Prior to the 1960s, the majority of rural students seeking an education moved from their village to regional population hubs to attend boarding schools. Based on western curricula, boarding schools did not recognize traditional ecological knowledge (TEK). Post-secondary education opportunities were only available in Fairbanks, Anchorage or Sitka, however, TEK
\end{abstract}


or Alaska Native world views were not addressed in science course offerings. Upon gaining the right to provide education at the local level, the North Slope Borough (NSB) of Alaska incorporated Iñupiat educational philosophies into the educational system. The NSB, in partnership with the University of Alaska Fairbanks, established Ilisagivik College, the only tribal college in Alaska. Now independently accredited, Ilisagivik offers 2-yr academic degrees and certificates in Allied Health programs, and is developing science, technology, engineering, and math (STEM) programs. Ilisagivik seeks to broaden STEM education on the North Slope to meet the needs of employers and research in fields such as climate science. Courses bridging TEK and western science have been developed as a means of introducing STEM education to North Slope students. These courses include summer science camps, workshops, college curriculum, and internships. Relationships between local and visiting educators, scientists, community scholars, and Elders facilitate closing the TEK and western science gap.

Keywords: Science, Education, Tribal College, Alaska Native, Traditional Ecological Knowledge

\section{Introduction}

In order to remain academically competitive with their urban peers, Alaska Native students residing in rural communities need to achieve a degree of competence in science, technology, engineering and math (STEM). Ideally, the combination of STEM competence and traditional knowledge will ensure the longevity of dynamic indigenous cultures in an increasingly technological world. To meet this need, faculty members at Ilisagivik Tribal College conduct workshops and camps with a modular, self-contained format. Student engagement can be encouraged by developing college curricula that incorporates place-based science modules with traditional ecological knowledge (TEK) (Duffy et al., 2011a). The modular format is associated with local science camps targeting youth in grades 7 through 12 as well as traditional undergraduates. The modules provide a practical means of presenting scientific content to rural, remote areas of the Arctic. Students learn from local and visiting scientists, scholars and Elders and integrate scientific concepts with local heritage and cultural experiences. The knowledge gained from integrating STEM content and TEK enables students to become active, informed employees, community members and leaders, a necessity as the extreme Arctic environment interfaces with technology.

Alaska's North Slope is a resource rich region occupying highly diverse coastal Arctic ecosystems. Scientists representing national and state agencies, as well as the oil and gas companies, intently research and monitor the effects of development on the landscape. An excellent vantage point to monitor global change and plan for national security, Barrow is inundated with scientists and science opportunities. Preparing local youth for employment and community leadership roles, Ilisagvik Tribal College offers STEM science camps to introduce students to short courses such as biotechnological skills workshops and citizen science projects with the North Slope Borough School District. 


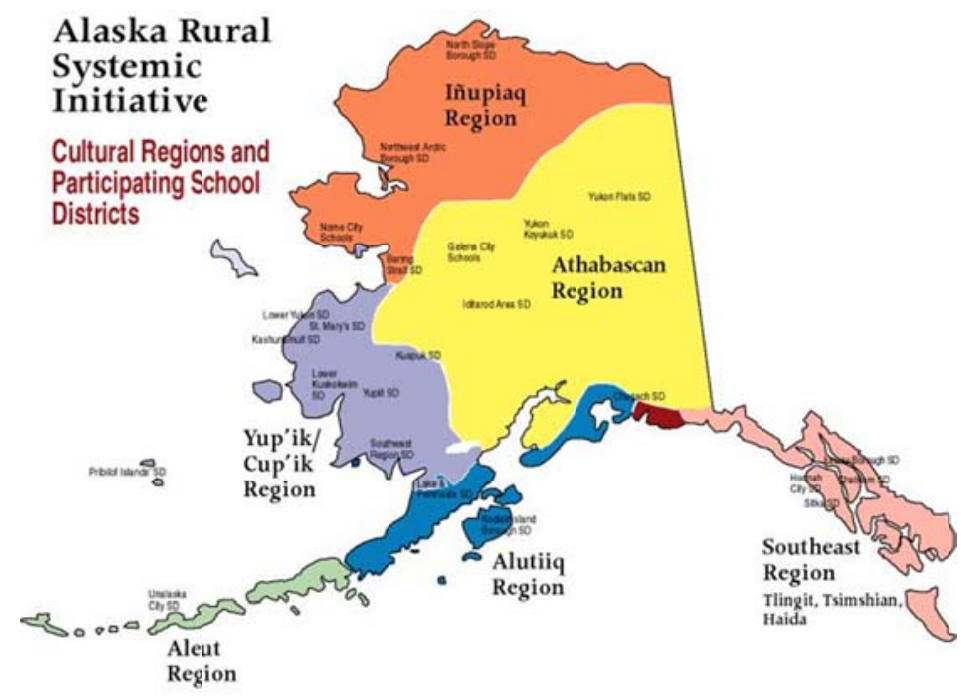

Figure 1. Alaska Native languages by region. Alaska Native Knowledge Network, University of Alaska Fairbanks

\section{Rural Alaska and Educational Philosophy}

Data from the 2010 Alaska census indicate a state population of over 710,000 residents of which approximately 290,000 lived in Anchorage (US Census Bureau, 2010). However, most of Alaska (40\%) is comprised of small, rural, and isolated communities that range between 25 and 5000 residents (Barnhardt, 2010). These rural communities are predominantly Alaska Native villages with a total population of 90,000 individuals. Divided into six major regions with distinct languages (Figure 1), many of these communities are accessible only by airplane or boat. Over 70 percent of these individuals live and practice their traditional cultures (Barnhardt, 2010), including traditional subsistence lifestyles of hunting, fishing, and gathering.

Alaska Natives in these rural communities rely on subsistence living as a major source of food, clothing, and raw materials. Although in some villages people can purchase provisions at general stores, the major components of their diet include wild plants and berries, fish, caribou, moose, walrus, whales, and other marine mammals. These foods are strongly tied to their cultural and spiritual identities (Barnhardt \& Kawagley, 2010).

Living a subsistence lifestyle youth learn values and skills from their Elders. They learn how to read the environment: land, oceans, rivers, and ice from a traditional ecological knowledge (TEK) perspective. This knowledge, passed down through the generations, is built on continuous observation and provides a rich source of instructional stories.

Patricia L. Cochran, former Executive Director of the Alaska Native Science Commission and former Chair of the Inuit Circumpolar Council is an Iñupiat raised in Nome, AK, and who now resides in Barrow. Interviewed as part of the Wisdom of the Elders radio program, Cochran told listeners: 
One of the things that people forget: traditional knowledge is dynamic; it is not static. The traditional knowledge I know not only came from my Mom and my grandparents, but it's different, and what I pass on to my grandchildren will be different. Traditional knowledge builds. And that's what it's about: it's just not knowledge from the past; it really builds from what I know today and what generations will teach. So that's really what traditional knowledge is - it's living every day ( $P$. Cochran, personal communication, September 11, 2013).

For Alaska Natives, the environment is their school; the Elders are the teachers; and the young men, women, and children are the students. These practices, which are passed to the next generation, contrast to the cultures of Western societies, especially in terms of spirituality and education. In the 1800's missionaries sought to create educational institutions designed not to enhance the Native ways of knowing, but to replace them. Translations were difficult between Alaska Native languages and English; therefore loss of language meant loss of traditional education. Children were sent away to boarding schools, away from their parents and grandparents, a significant disruption to their multi-generational education. As a result of the Molly Hootch legal decision (Tobeluk v. Lind) ${ }^{1}$, boarding schools were eventually replaced by a western style, state-funded school system. Up to the early 1900's, Native knowledge and western science were classified as two mutually independent systems (Barnhardt, 2005; Figure 2). Steven Dinero (2004) discussed the difficulties associated with the western educational style: Western curricula are not conducive to meet the needs of the Native societies; rather they are means of transformation to Western societal norms. This "social control" can often lead to "culturally insensitive curricula and pedagogy."

\footnotetext{
${ }^{1}$ Prior to the Tobeluk v. Lind decision, lack of local, quality secondary school facilities resulted in a boarding school model for high school students. Students who chose to continue their education beyond elementary school were immersed in an educational setting that was both geographically and culturally removed from their place of origin. This situation often led to mistreatment of Alaska Native students and a high drop rate (Haycox, 2006). The signing of the Tobeluk Dissent Decree committed the state of Alaska to build high schools in the local communities.
} 


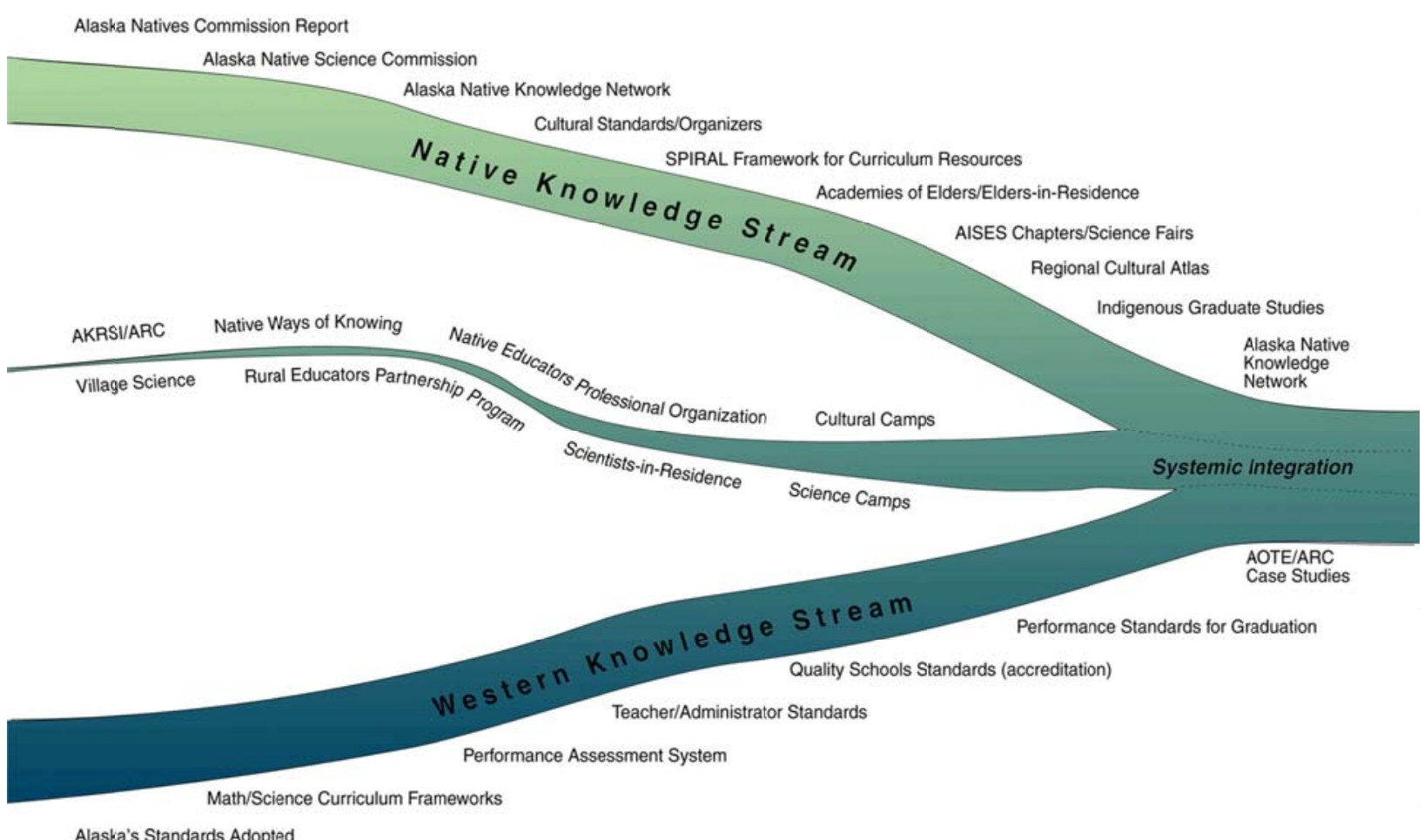

Alaska's Standards Adopted

Figure 2. Two independent knowledge systems: Native knowledge stream and Western knowledge stream. Alaska Native Knowledge Network (Barnhardt, 2005)

\section{North Slope Borough and Education}

Occupying 15 percent of Alaska's land mass (89,000 square miles), the North Slope is home to 10,000-plus residents, the majority of whom (76.4 percent) are Iñupiat Eskimo (Shepro, 2010). North of the Arctic Circle, North Slope Borough is made up of eight villages: Anaktuvuk Pass; Atqasuk; Barrow; Kaktovik; Nuiqsut; Point Hope; Point Lay and Wainwright (Figure 3). The largest populated village is Barrow with over 4,500 residents and the next largest village, Point Hope, has approximately 700 residents. Point Lay is the smallest village with approximately 200 residents.

The North Slope Borough was created shortly after the 1971 passage of the Alaska Native Claims Settlement Act (ANSCA). This major political event unified the North Slope villages and provided a framework for the borough to provide economic, education, social service, and other cultural benefits, as well as the funding to deliver these services. The Iñupiat people decided that regulation, taxation, as well as the educational needs of their people should be supported by their own local government. (Barnhardt \& Harrison, 1993). A few years after assuming this control, Eben Hopson, the first mayor of the Borough, made the following observation:

Today, we have control over our educational system. We must now begin to assess whether or not our school system is truly becoming an Iñupiat school system, reflecting Iñupiat educational philosophies, or, are we in fact only theoretically 
exercising "political control" over an educational system that continues to transmit white urban culture? Political control over our schools must include "professional control" as well, if our academic institutions are to become an Iñupiat school system able to transmit our Iñupiat traditional values and ideals (Hopson, 1977).

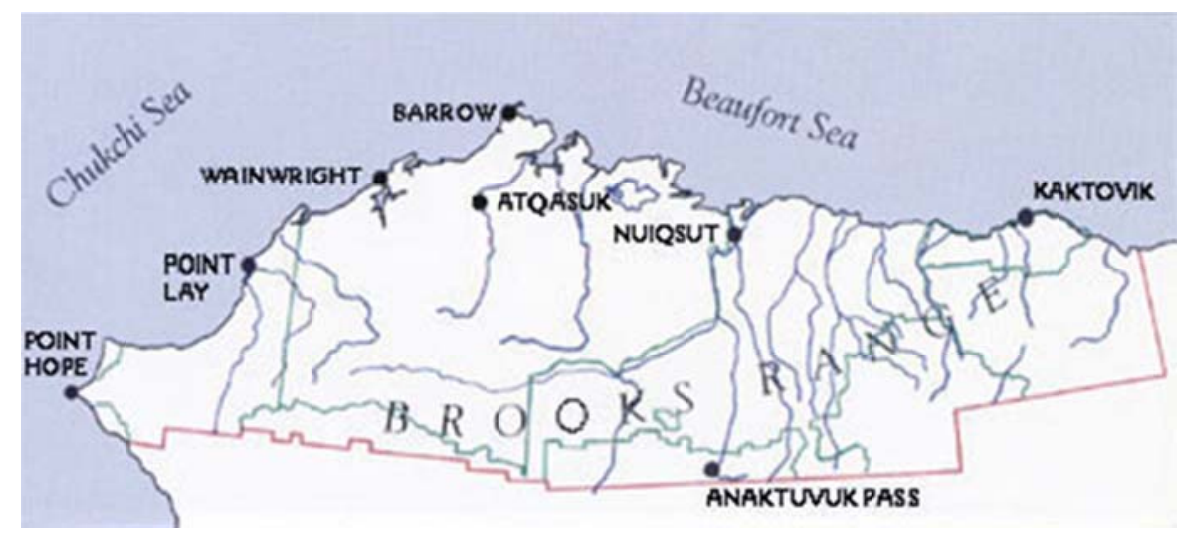

Figure 3. Eight villages of the North Slope Borough. Education through Cultural and Historical Organizations (http://www.echospace.org/articles/387/print.html)

In order to facilitate "professional control," leaders believed the schools had to be staffed with Iñupiat teachers and administrators and this, in turn, constituted merging Iñupiat educational philosophies with those of Western education at the post-secondary level (Barnhardt, 1999; Figure 2). In 1986, the North Slope Borough created the North Slope Higher Education Center. The North Slope Borough partnered with the University of Alaska Fairbanks (UAF) to facilitate this transition from a center to a tribal college, and for the new college to operate until independent accreditation was achieved. The North Slope Higher Education Center's Board and the North Slope Borough Assembly changed the institution's name to Arctic Sivunmun Ilisagivik College in 1991. In 1995, the North Slope Borough established by ordinance the Ilisagivik College Corporation.

In 2006, after two decades of effort, Ilisagivik College was recognized as a Tribal College, the first and only Tribal College in Alaska. Located in the former Naval Arctic Research Laboratory facilities, Il isagivik College provides academic, vocational, and technical education with one of its missions being the incorporation of traditional values and traditional ways of knowing in STEM courses. Ilisagivik College serves the eight villages of the North Slope and has recently extended services to villages and communities outside of the official borough boundaries.

Using the 2012-13 as a typical academic year, Ilisagivik has a student population, which can be characterized by age, gender, and race. $68 \%$ of students enrolled in courses were age 25 and older. The female enrollment was $56 \%$ and males $44 \%$. Ilisagivik as a tribal college has maintained the Alaska Native student population of $51 \%$. Enrollment increased from an 
average of 500 students per year $(2004-2007)$ to an average of 675 students per year (2008 - 2013) (Figure 4).

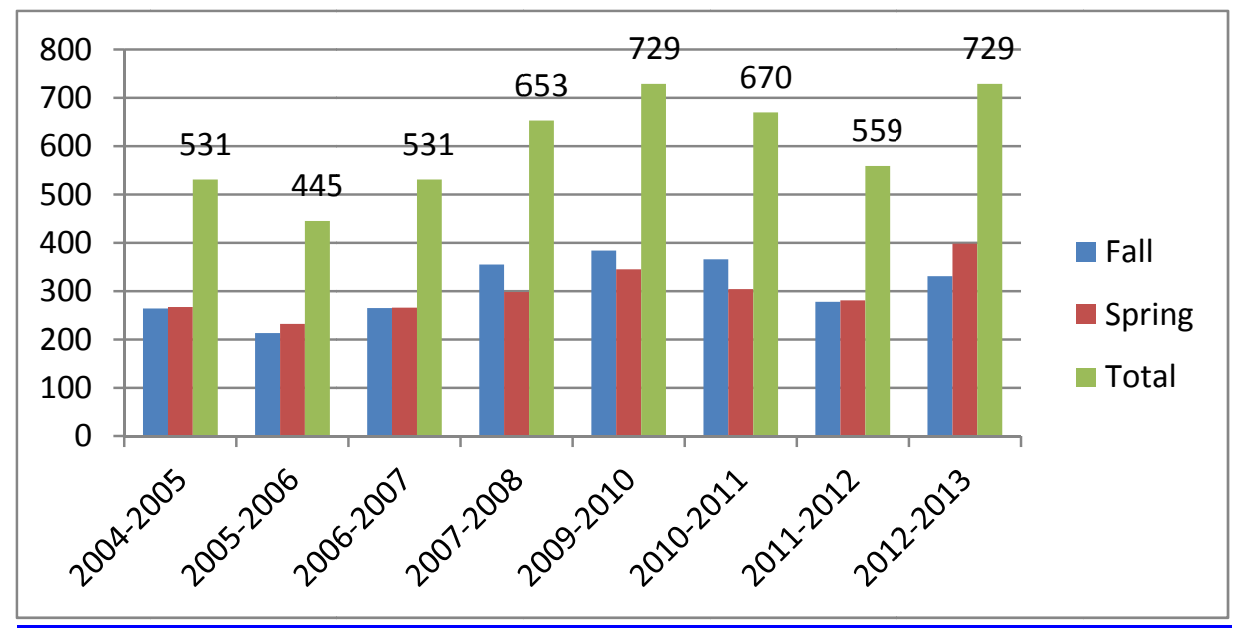

Figure 4. Ilisaġvik enrollment trends from Fall 2004 to Spring 2013. Ilisaġvik College Institutional Research Report, 2013

Illisaġvik's degree programs include General Studies, Business, Inupiaq Studies, and Allied Health. The Allied Health program is currently the primary STEM relatedl program delivered by the college and strives to meet growing workforce needs. The Associate Degree in Liberal Arts acts as a feeder program to the University of Alaska (UA) System and allows students to remain close to their home and land as they begin their post-secondary education. Ilisagivik College continues to improve the foundation science courses necessary for completion of the Liberal Arts degree through the incorporation of TEK. As it plans for future growth in the community, Ilisagivik is striving to meet the broad employment demands of expanding resource development thus increasing the likelihood of retaining local talent.

\section{STEM and Alaska Natives}

STEM disciplines are tightly linked to innovation and economics in Alaska. A report published in the Springboard Program for the Juneau Economic Development Council (2010) describes STEM education goals for Alaskans as 1) an approach that connects several disciplines rather than learning each one separately preparing them for real-life situations; 2) to foster students ability to solve problems; 3) to enhance their learning environments through discovery and; 4) a move to drive STEM literacy into the classrooms for ALL students (Sorenson, 2010). Quality STEM education needs to be delivered and minority students should be recognized in these efforts (National Science Board, 2010; Hussar \& Bailey, 2008).

For Alaska and the North Slope, this underrepresented group is essential to both local control of the educational process and the development of a strong workforce. Previous studies concluded that underrepresented minorities of African Americans, Hispanics, and Alaska 
Native/American Indian (AN/AI) are less likely to be noticed as talented students compared to Caucasians and Asian/Pacific Islanders (Gandara, 2005; Learning Point Associates, 2004; Hoffman \& Llagas, 2003; Hunt \& Bailey, 2008). Within these underrepresented minorities, AN/AI students have the highest high school dropout rates (Swanson, 2004), and have among the lowest college entrance and retention rates in the country (Devoe \& Darling-Churchill, 2008; Hunt \& Harrington, 2008). Alaska rural communities, populated primarily by Alaska Natives, are at a further disadvantage as the secondary schools cannot offer a wide range of advanced courses or placement exams.

One remedy was the development of a culturally responsive science curriculum as described by Barnhardt and others:

Culturally responsive science curriculum attempts to integrate Alaska Native and Western knowledge systems around science topics with goals of enhancing the cultural well-being and the science skills and knowledge of students. It assumes that students come to school with a whole set of beliefs, skills and understandings formed from their experiences in the world. The role of STEM education is not to ignore or replace prior understanding, but to recognize and make connections to that understanding. It assumes that there are multiple ways of viewing, structuring, and transmitting knowledge about the world-each with its own insights and limitations (Figure 2). It thus values both the rich knowledge of Native Alaskan cultures and of Western science and regards them as complementary to one another in mutually beneficial ways (Barnhardt, 2006 and Stephens, 2003).

Students can become involved in gathering and documenting local knowledge and culture by obtaining relevant information from sources such as families, resource people/scholars, Elder groups or others. This knowledge can be incorporated into modules that can be continuously updated. To better enhance the learning abilities for Alaska Native students, cultural relevance can be integrated into STEM curriculum (Duffy et al., 2009; Duffy et al., 2011b).

\section{Partnerships}

Beginning in 1995 and supported by the National Science Foundation, the University of Alaska Fairbanks (UAF) and the Alaskan Federation of Natives (AFN), in partnership with Alaska Native communities, endeavored to create a research-based STEM curriculum. This initiative, the Alaska Rural Systemic Initiative (AKRSI), was aimed at fostering a connection between the current abstract scientific pedagogy and practical Indigenous knowledge. In AKRSI's final report, the Alaska Native enrollment at the state university, UAF, showed significant increased enrollment in biology and wildlife, chemistry and biochemistry, geology, and math. The enrollment in these STEM fields increased from 36 in 1994 to 84 in 2000. The selection of the STEM majors illustrated and supported the concept that relevance to everyday activities and place-based issues could connect science to rural Alaska Native students. This initiative also demonstrated the importance of establishing an explicit pathway in which rural students are exposed early and continuously to relevant STEM ideas. This pathway is a good example of rural Alaska's adaptation and cultural resilience. 


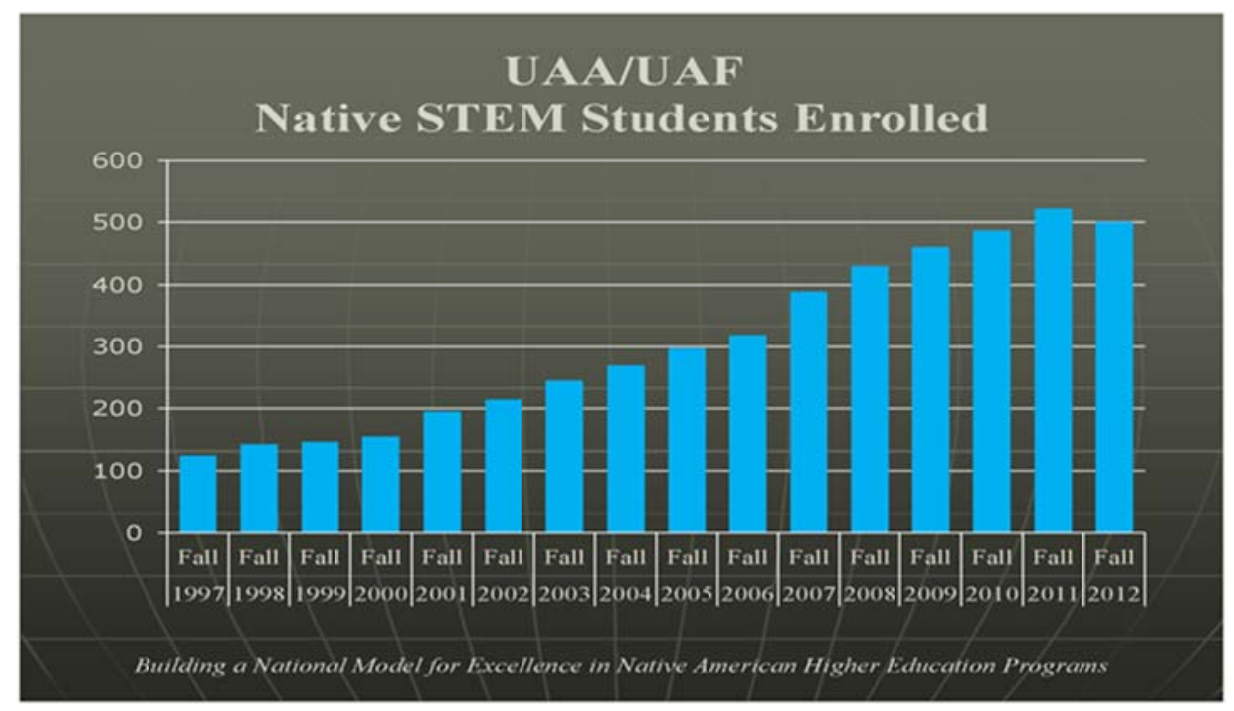

Figure 5. Alaska Native STEM students enrolled at UAA/UAF from Fall 1997 to Fall 2012. Alaska Native Science and Engineering Program (www.ansep.net/statistical-data.html)

More recently, Alaska Native STEM students enrolled in the UA system showed a steady increase from fall semester 1997 with 100 students to 500 plus students in fall semester 2011 (Figure 5). Graduation rates increased proportionately to enrollment (Figure 6). Many of these Alaska Native STEM graduates began their education at community colleges, including Ilisagivik. These pathway students are now populating graduate programs.

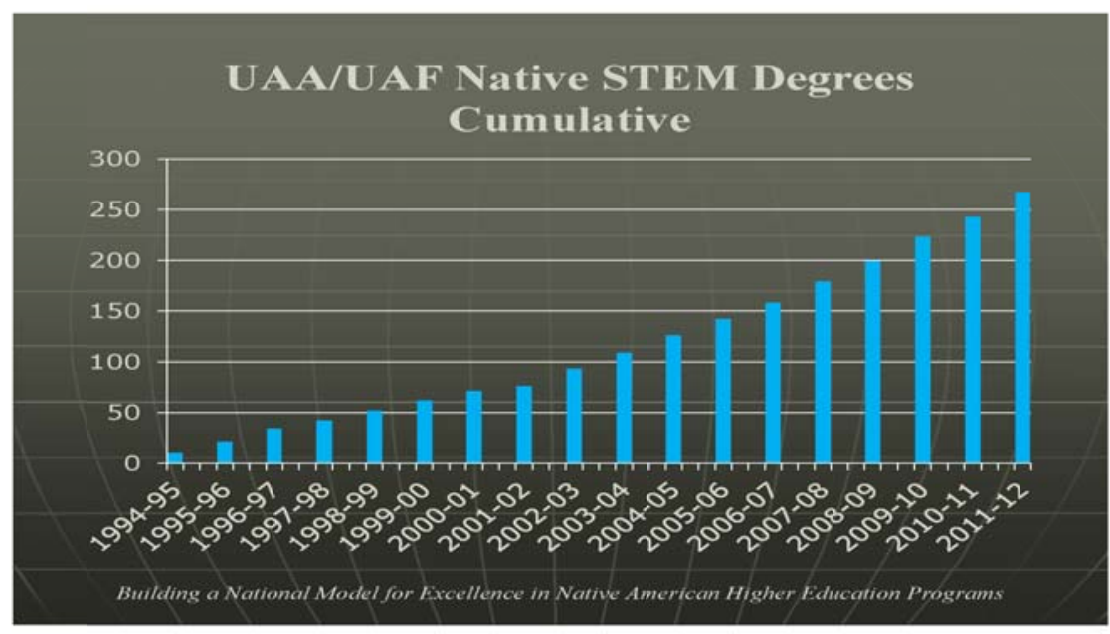

Figure 6. Cumulative UAA/UAF Alaska native STEM Degrees, 1994 - 2012. Alaska Native Science and Engineering Program (http://www.ansep.net/statistical-data.html) 
Ilisagivik College promotes STEM education to North Slope secondary school students through a curriculum that follows the Iñupiaq Learning Framework (ILF) and incorporates Iñupiat heritage and traditions into state and federal guidelines. The curricula is supported by the STEM science camps which introduce students to 1) short courses such as biotechnological skills workshops and 2) citizen science projects with the North Slope Borough School District. In partnerships with Ukpeagivik Iñupiat Corporation Science and the North Slope Borough Department of Wildlife Biology, Ilisagivik Tribal College faculty members are developing internships for college and high school students.

One recent and highly successful activity, the Ilisagivik STEM high school summer camp, was initiated in 2011. The camp was located at campus facilities in Barrow and provided students with college credit upon completion. This camp was run for middle school students in 2012 - 2013. This camp was a model for a second STEM camp for high school students in 2012 and 2013. Culturally relevant, these summer science courses emphasized the impacts of climate change within the North Slope Borough and were the result of a partnership formed between Ilisagivik, UAF, and supported by the Arctic Slope Community Foundation, American Indian Higher Education Consortium, University of Illinois at Urbana-Champaign, and Smithsonian Institution's National Museum of the American Indian.

A powerful example of how partnerships can effectively integrate western science and TEK principles occurred during the 2012 summer camp. A visiting educator was teaching Aurora Alive, a comprehensive UAF developed multimedia course with over 100 hands-on math, science and physics lessons that taught the science and research behind the Aurora borealis. The students were engaged. The majority of students live where the Aurora is visible on dark, clear nights. Two Inupiat Elders visited the camp and spoke about the aurora and retold the associated legend that encouraged children to return home at a reasonable hour. They sang a song in Inupiaq, to the tune of jingle bells, with the students joining in.

In addition, the elders discussed current environmental changes: thinning Arctic Ocean ice that affects the spring whale hunts and the longer fall fishing season due to late freezing lakes. They have observed willows growing taller and bushier while salmonberries and crow berries are found growing further north. The people are catching more salmon than they did growing up. By the end of the class period, the students began to speak about the changes they have seen in their lifetimes. This engaging dialogue between students and Elders sparked student interest and resulted in greater discussion of ecological change. The Elders encouraged the youth to study science and use their cultural knowledge to come to their own conclusions.

\section{Ilịagagik College STEM Curriculum Adaptation}

Ilisagivik College science courses consisted of the typical courses one would see at most universities or community colleges. This type of abstract science course did not generate student interest. For example, a general education science course listed under Geological Science, "An Introduction to Earth Science," has had no enrollment the last several offerings. In contrast, a newly developed course, "Indigenous Science and Traditional Ecological Knowledge," listed under Geological Science had 3 and 5 students in its first two offerings, 
respectively. The classical geology in the introductory course is now presented in a place-based relevant format.

A second new course, "Climate Change and the North Slope Community," engages students in the changes in climate and permafrost specifically on the North Slope. The students involve Elders through interviews to acquire their perspectives, experiences, and observations on this subject. These courses offer a different insight on how a student can study science while at the same time apply this science to what is relevant and important to their village or community. They fit the model suggested by Inupiaq Elder Patricia Cochran: knowledge grows with everyday environmental experiences.

\section{Conclusion}

STEM education is important throughout the United States. However, African Americans, Hispanics, and Alaska Native/American Indian enrollment in STEM curricula are underrepresented. In rural communities, such as Alaska's North Slope, advanced education in general, and STEM in particular is improving. The provision of STEM education to rural Alaska students should integrate western science and Indigenous knowledge. This can be accomplished by introducing STEM to youth and undergraduates through college curriculum, workshops, summer camps, and discussions with Elders.

Workshops providing culturally relevant hands-on STEM activities related to the environment, land animals, and marine animals can be developed and delivered on weekends to the local youth throughout the school year and in summer camps. This weekend exposure may lead to greater interest in science and provide a better foundation for college courses. During the summer science camps, Elder participation can be extended beyond casual conversation. Elder scholars and visiting scientists can "team up" and instruct together. Co-presentation in the classroom, on field trips and during activities would emphasize the importance of learning a concept from both the western and Indigenous perspective. Elders can participate in existing and new college curricula through class visits and interviews. It would be a beneficial adaptation for one Elder to provide guidance of local Indigenous knowledge for a particular STEM subject throughout the course of the semester.

\section{Acknowledgements}

This study was supported, in part, by NSF DUE-045586, 1356766 and 0632369. We are grateful to the leadership and staff at Ilisagivik Tribal College for the tireless support of the science camps and modules.

\section{References}

AKRSI. (2005). Alaska Rural Systemic Initiative Final Report. Retrieved from http://www.ankn.uaf.edu/download/AKRSI2005FinalReport.doc

Barnhardt, R. (1991). Higher Education in the Fourth World: Indigenous People Take Control. Canadian Journal of Native Education, 18(2). Retrieved from http://ankn.uaf.edu/IEW/WINHEC/FourthWorld.html 
Barnhardt, R. (1999). Culture, Chaos and Complexity: Catalysts for Change in Indigenous Education.

Retrieved

from

http://ankn.uaf.edu/Curriculum/Articles/BarnhardtKawagley/ccc.html

Barnhardt, R. (2005). Culture, community, and place in Alaska Native education. Democracy and education.

Retrieved

from

http://ankn.uaf/Curriculum/Articles/RayBarnhardt/CultureCommPlaceANE.html

Barnhardt, R. and Harrison, B. (1993). Developing Tribal Education Strategies in Indigenous Communities. In Discourse: the Austrialian Journal of Educational Studies. Retrieved from http://ankn.uaf.edu/Curriculum/Articles/TribalEducationStrategies.html

Barnhardt, R., \& Kawagley, O. A. (2010). Alaska Native Education Views From Within: Alaska Native Knowledge Network, Center for Cross-cultural Studies, University of Alaska Fairbanks.

DeVoe, J., \& Darling-Churchill, K. (2008). Status and trends in education of American Indians and Alaska Natives. (NCES 2008-08). Washington, DC: National Center for Education Statistics, Institute of Education Sciences, U.S. Department of Education. Retrieved from http://nces.ed.gov/pubs2008/2008084_1.pdf

Dinero, S. (2004). The Politics of education provision in rural Native Alaska: the case of Yukon Village. Race Ethnicity and Education, 7(4), 401-419. http://dx.doi.org/10.1080/1361332042000303405

Duffy, L., Middlecamp, C., Godduhn, A., \& Fabbri, C. (2009). Using Culture, Policy and Traditional Knowledge to Improve Engagement in Science Courses. American Journal of Applied Sciences, 6(8), 1560-1566. http://dx.doi.org/10.3844/ajassp.2009.1560.1566

Duffy. L., Godduhn, A., Fabbri, C., van Muelken, M., Nicholas-Figueroa, L., \& Middlecamp, C. (2011a). Engaging Students in Science Courses: Lessons of Change from the Arctic. Interchange A Quarterly Review of Education, 42(2), 105-139.

Duffy, L., Godduhn, A., Dunlap, K., van Muelken, M., \& Middlecamp, C. (2011b). Sustainability and Chemistry: Key concepts in an Arctic focused interdisciplinary course. In Sustainability in the Chemistry Curriculum, (Middlecamp, C and Jorgenson, A eds) American Chemical Society Symposium, 1087 (pp. 98-112). Washington, DC.

Gandara, P. (2005). Fragile futures: Risk and vulnerability among Latino high-achievers. Princeton, NJ: Policy Evaluation and Research center, Educational Testing Service. Retrieved from http://www.ncrel.org/gap/studies/allsdudents.pdf

Haycox, S. (2006). Alaska: An American Colony. University of Washington Press. p. 285. Seattle, WA.

Hoffman, K., \& Llagas, C. (2003). Status and trends in the education of blacks (NCES 2003-034). Project Officer: T.D. Snyder. National Center for Education Statistics. Washington, DC: U.S. Department of Education. Retrieved from http://nces.ed.gov/pubs2003/2003034.pdf 
Hopson, E. (1977). Inupiaq education. In R. Barnhardt (Ed.), Cross-cultural issues in Alaskan education (pp. 3-6). Fairbanks, AK: Alaska Native Knowledge Network, University of Alaska. Retrieved from http://www.ankn.uaf.edu/Curriculum/CXCS/Issues1/Hopson.html

Hunt, B., \& Harrington, C. (2008). The impending education crisis for American Indians: Higher education at the crossroads. Journal of Multicultural, Gender and Mineral Studies. 2(2) , 1-11. Retrieved from http://www.scientificjournals.org/journals2008/articles/1393.pdf.

Hussar, W., \& Bailey, T. (2008). Projections of education statistics to 2017 (NCES 2008-078). National Center for Education Statistice, Institute of Education. Washington, DC; U.S. Department of Education. Retrieved from http://nces.ed.gov/pibs2008/2008078.pdf

Learning Point Associates. (2004). All students reaching the top: Strategies for closing academic achievement gaps. Naperville, IL: North Central regional Educational Laboratory. Retrieved from http://www.ncrel.org/gap/studies/allsdudents.pdf

National Science Board. (2010). Higher education in science and engineering. In Science and engineering indicators 2010 (pp. 13). Arlington VA: National Science Foundation. Retrieved from $h t t p / / . w w w . n s f . g o v / s t a t i s t i c a s ? s e i n d 10 / p f g . s e i n d 10 . p d f$.

Shepro, C. (2010). The North Slope Borough Economic Profiles and Census Reports. Retrieved from http://www.north-slope.org/departments/mayorsoffice/census_data_2010.php

Sorenson, B. (2010). Alaska STEM Education and the Economy, Report on the Need for Improved Science, Technology, Engineering and Mathematics Education in Alaska. pp. 8. Retrieved from http://www.jedc.org/research-library-reports-studies-jedc

Stephens, S. (2003). Handbook For Culturally responsive science curriculum. Fairbanks, AK: Alaska Native Knowledge Network. Retrieved from http://www.ankn.uaf.edu/publications/handbook/

Swanson, C. (2004). Who graduates? Who doesn't? A statistical portrait of public high school graduation, class of 2001. Washingto, DC: The Urban Institute. Retrieved from www.urban.org/UploadedPDF/410934_WhoGraduates.pdf

US Census Bureau. (2010). US Department of Commerce. Retrieved from http://quickfacts.census.gov/qfd/states/02000.html

\section{Copyright Disclaimer}

Copyright reserved by the authors.

This article is an open-access article distributed under the terms and conditions of the Creative Commons Attribution license (http://creativecommons.org/licenses/by/3.0/). 